\title{
STUCK AT A CROSSROAD? SUBSTANTIVE LEGITIMATE EXPECTATIONS IN ENGLISH LAW
}

\author{
AlisOn L. YounG*
}

\begin{abstract}
In "The Provenance and Protection of Legitimate Expectations" Forsyth argued that English law should protect substantive legitimate expectations. However, he was concerned that too great an expansion of legitimate expectations could lead to incoherence and intuitive decision-making. I argue that recent case law, and Forsyth's analysis, have clarified some of these inconsistencies. Nevertheless, the doctrine of legitimate expectations stands at a crossroads. Should it adopt a rules-based approach and narrow legitimate expectations, or a principled approach that embraces a broader conception? I argue that English law needs both for legitimate expectations effectively to balance legal certainty and substantive equality.
\end{abstract}

KEYwORDs: administrative law, substantive legitimate expectations, judicial reasoning.

\section{INTRODUCTION}

Much has happened since 1988, when Christopher Forsyth, now the Emeritus Sir David Williams Professor of Public Law at the University of Cambridge, set out to clarify the then newly emerging protection of legitimate expectations in English law in "The Provenance and Protection of Legitimate Expectations". ${ }^{1}$ Forsyth made three main claims and one prediction. First, he argued that there were circumstances in which, even in 1988, English law had sporadically protected substantive legitimate expectations and that the law should do so more generally. ${ }^{2}$ Second, he explained how the origin and underpinning of legitimate expectations was the German principle of Vertrauenschutz - the protection of promises and of trust in the administration. ${ }^{3}$ This promotes legal certainty, which needs to be balanced against legality to ensure that the protection of a substantive legitimate expectation does not place too great a fetter on the discretionary

\footnotetext{
*Alison L. Young, Sir David Williams Professor of Public Law, University of Cambridge, and Fellow of Robinson College. Address for Correspondence: Robinson College, Grange Road, Cambridge CB3 9AN, UK. Email: aly23@cam.ac.uk. The author wishes to thank the editor and the anonymous reviewers for comments on an earlier draft. All responsibility for errors remains with the author alone.

1 C. Forsyth, "The Provenance and Protection of Legitimate Expectations" [1988] C.L.J. 238.

2 Ibid., at 240 .

Ibid., at $241-45$.
} 
powers of the administration. Third, Forsyth expressed concern over the extension of the doctrine of legitimate expectations beyond lawful representations. To extend legitimate expectations to include ultra vires representations "would be to create that legal horror: a body that can set its own limits to its jurisdiction". ${ }^{4}$ Forsyth's prediction was that the general protection of substantive legitimate expectations would be confirmed.

Despite a rocky start, the general protection of substantive legitimate expectations in English law was finally confirmed 11 years after Forsyth wrote his article, in the ground-breaking Coughlan case. ${ }^{5}$ The Court of Appeal drew on statements in the 7th edition of Wade and Forsyth's Administrative Law, and also recognised the grounding of substantive legitimate expectations on the need to protect promises, balancing legal certainty and legality. Moreover, at the time of writing, legitimate expectations in English law cannot arise from an ultra vires representation where this is beyond the power of the public body as a whole and not merely the powers of the individual agent of that body whose actions created the legitimate expectation. ${ }^{6}$

It is not often that an academic article is able to achieve such a successful impact upon the law. However, Forsyth's prescience was not just limited to the confirmation of the protection of substantive legitimate expectations. Forsyth also recognised that "[p]ublic authorities may, through their conduct, cause an infinitely various array of legitimate expectations in the minds of those subject to them". ${ }^{7}$ This insight has also proven to be true. Writing 23 years after his original article, Forsyth recognised the explosion of case law and academic writing relating to substantive legitimate expectations. This prompted in Forsyth the "sombre reflection" that "[t]here is a real danger that the concept of legitimate expectation will collapse into an inchoate justification for judicial intervention. It sounds so benign who could be against the protection of legitimate expectations? - but, it seems to me, as sometimes interpreted, the concept often gives little guidance and plays at best a rhetorical role". ${ }^{8}$

It is hard to disagree with this conclusion. Indeed, Coughlan arguably added to the confusion, creating three categories of legitimate expectations the boundaries of which are, at best, malleable, and, at worst, non-existent. First, this article explores more recent case law on substantive legitimate expectations to assess whether the concept of legitimate expectations has collapsed into "an inchoate justification for judicial intervention". ${ }^{9}$ It will argue that this is not the case. It is possible to provide a level of clarity surrounding the core case of when an individual will be able successfully to

\footnotetext{
${ }^{4}$ Ibid., at 240.

R. v North and East Devon Health Authority, ex parte Coughlan [2001] Q.B. 213 (C.A.).

${ }^{6}$ Western Fish Products v Penwith District Council [1981] 2 All. E.R. 204.

Forsyth, "The Provenance and Protection of Legitimate Expectations", 250.

8 C. Forsyth, "Legitimate Expectations Revisited" (2011) 16 Judicial Review 429, 429.

9 Ibid.
} 
rely on a substantive legitimate expectation. However, it is nevertheless the case that difficulties arise both as to distinguishing the doctrine of legitimate expectations from other doctrines in English administrative law and when determining borderline issues.

Second, the article will argue that English law appears to be at a crossroads. One path leads to a narrowing of the doctrine of legitimate expectations. This direction would confine legitimate expectations to those core cases where the administration has provided a clear and precise promise to a small group of individuals, who, preferably, have relied on this promise to their detriment. The other path embraces a wider view of legitimate expectations, recognising the multiple values underpinning legitimate expectations and the array of methods through which these values and expectations can be protected in English law.

These paths also adopt different approaches to judicial reasoning. The first focuses on establishing a clear set of legal tests that need to be satisfied in order to create a legitimate expectation. Once this test has been satisfied by the applicant wishing to protect a legitimate expectation, the courts balance legal certainty and legality to determine whether there are sufficiently strong reasons for resiling from that legitimate expectation. Here, usually, the public authority provides a justification for failing to protect a legitimate expectation. The second path tends to produce judgments which reason from first principles. An array of factors is balanced by the court to determine whether a legitimate expectation should be protected, or whether there are good reasons for resiling from the expectation.

Forsyth would adopt the first path. However, I would argue that the second path is also needed. Adopting a protection of legitimate expectations that draws from first principles, balancing the reasons for and against protecting a specific legitimate expectation, would not mean that the concept of legitimate expectations played a mere "rhetorical role". ${ }^{10}$ Nor would it give the courts carte blanche to intervene in administrative decisions merely because they felt that the wrong decision had been reached. It would, however, ensure that some instances of bad administration which undermine legal certainty and trust in the administration do not inadvertently go unchecked. Rather than choosing between them, both paths need to remain available if we are to maintain the correct balance between legal certainty and legality.

\section{PLUS ÇA CHANGE}

As with most developments in the common law, although one key case is credited with establishing the origins of a particular common law doctrine or head of judicial review, its origins can be tracked through a series of earlier cases. This is no surprise. The common law has always developed

${ }^{10}$ Ibid. 
incrementally. With regard to the development of substantive legitimate expectations, earlier case law both helped to shape the development of the legal protection for substantive legitimate expectations and also provided a dramatic backdrop, pointing out deep divisions over whether substantive legitimate expectations should be protected in English law. Hirst L. J. infamously described the approach of Sedley L.J. in Hamble Fisheries, ${ }^{11}$ which had recognised the existence of a substantive legitimate expectation, albeit one that was not protected as there were good reasons of public policy to resile from that expectation, as a "heresy". ${ }^{12}$ However, the further we examine the categories established in Coughlan, the more we realise both that the earlier case law did not help to provide clarity and that later case law decided shortly after Coughlan led to further confusion.

Coughlan concerned a promise given to Mrs. Coughlan and others that, if they were to move from their current hospital facilities to a new facility, Mardon House, this would be their "home for life". ${ }^{13}$ Coughlan and others duly agreed to move. However, following a later change in central government policy, the North and East Devon Health Authority decided to close Mardon House. Mrs. Coughlan argued, inter alia, that to do so would frustrate her substantive legitimate expectation. The Court of Appeal agreed, both that Mrs. Coughlan had a substantive legitimate expectation to remain in Mardon House and also that the actions of the local authority to close Mardon House, thereby resiling from a legitimate expectation, amounted to an abuse of power. In doing so, Lord Woolf M.R. distinguished between three possible outcomes. First, "[t]he court may decide that the public authority is only required to bear in mind its previous policy or other representation, giving it the weight it thinks right, but no more, before deciding whether to change course". ${ }^{14}$ Second, "the court may decide that the promise or practice induces a legitimate expectation of, for example, being consulted before a particular decision is taken". ${ }^{15}$ Third, "[w]here the court considers that a lawful promise or practice has induced a legitimate expectation of a benefit which is substantive, not simply procedural, authority now establishes that here too the court will in a proper case decide whether to frustrate the expectation is so unfair that to take a new and different course will amount to an abuse of power". ${ }^{16}$

Two cases were provided as illustrations of the first category, Findlay and Hargreaves, both of which concerned a change of policy regarding the early release of prisoners. ${ }^{17}$ The case provided to illustrate the second

${ }^{11}$ R. v Ministry of Agriculture Fisheries and Food, ex parte Hamble (Offshore) Fisheries Ltd. [1995] 2 All E.R. 714.

${ }_{12}$ R. v Secretary of State for the Home Department, ex parte Hargreaves [1997] 1 W.L.R. 906.

13 Coughlan [2001] Q.B. 213 (C.A.).

${ }^{14}$ Ibid., at [57].

15 Ibid.

16 Ibid. (emphasis in original).

${ }^{17}$ In re Findlay [1985] A.C. 318; Hargreaves [1997] 1 W.L.R. 906. 
category was $\mathrm{Ng}$ Yuen Shiu, where the Government announced that illegal immigrants from Macau, residing in Hong Kong, would be interviewed, with cases treated on their own merits if they came forward. ${ }^{18}$ This gave rise to a procedural legitimate expectation. Case law which illustrated the third category was supplied by cases concerning promises made to specific taxpayers as to how the Inland Revenue would assess their tax affairs, from which the Inland Revenue later sought to depart. ${ }^{19}$

There are three possible ways in which we could use the differences between Findlay and Hargreaves and Coughlan to help distinguish between the first and third category of substantive legitimate expectations. First, Findlay and Hargreaves could be examples of situations where, on the facts, the applicants did not have a legitimate expectation at all. Coughlan, in contrast, is an example of where, on the facts, the applicants did have a legitimate expectation. In Findlay, the Home Secretary had a discretion to release prisoners on licence following the recommendation of the parole board. The Home Secretary changed his policy, such that he would not release certain categories of offenders for parole until they were in the final months of their sentence or had served at least 20 years of a mandatory life sentence. It was argued that this would frustrate the legitimate expectations of those prisoners who may have expected an earlier release on parole prior to this change of policy. The Court of Appeal, however, concluded that there was no legitimate expectation on the facts: "the most that a convicted prisoner can legitimately expect is that his case will be examined individually in the light of whatever policy the Secretary of State sees fit to adopt provided always that the adopted policy is a lawful exercise of the discretion conferred upon him by the statute." 20

In Hargreaves the Home Secretary changed the policy on home leave. The old policy of granting home leave to those prisoners who had been of good behaviour and had served at least a third of their sentence was changed. Under the new policy, prisoners had to be of good behaviour and to have served at least half of their sentence to qualify for home leave. The Court of Appeal concluded that, on the facts, this did not amount to a legitimate expectation that they would only have to serve one-third of their sentence to qualify for home leave. Instead, the only expectation that was legitimate on the facts was that prisoners would have applied to them whatever policy was in place at the time. ${ }^{21}$ The information provided to prisoners about home leave was insufficiently clear and unambiguous to give rise to a legitimate expectation that home leave would be granted after serving one-third of a sentence. Interpreted "through the eyes of an

18 Attorney General for Hong Kong v Ng Yuen Shiu [1983] 2 A.C. 629 (P.C.).

19 R. v Inland Revenue Comrs., ex parte Preston [1985] A.C. 835 and R. v Inland Revenue Comrs., ex parte Unilever plc [1996] S.T.C. 681.

${ }^{20}$ Findlay [1985] A.C. 318, 338.

21 Hargreaves [1997] 1 W.L.R. 906, 922, 925. 
ordinary prisoner" the compact signed by prisoners only made it clear that home leave was available to prisoners when they became eligible, with no information being provided as to the timing of that eligibility. ${ }^{22}$

In Coughlan, however, there was sufficient evidence to support the claim that Mrs. Coughlan had a substantive legitimate expectation that Mardon House would be her home for life. She had received a letter from the then general manager of the local health authority providing assurances as to the quality of care at Mardon House for as long as she chose to remain there. The health authority also accepted that these reassurances, coupled with other evidence, amounted to a representation to Mrs. Coughlan that Mardon House would be her home for life. ${ }^{23}$

Second, Findlay and Hargreaves could be examples of where, on the facts, the applicants did have a substantive legitimate expectation, but that the expectation did not match the criteria required to trigger the new head of judicial review of substantive legitimate expectations set out in the third category of substantive legitimate expectations in Coughlan. ${ }^{24}$ Instead, both were examples of where only Wednesbury would apply. No specific representation was made to the prisoners in Findlay. They were relying on the guidelines governing how the Home Secretary exercised his discretionary powers that were in place when they were sentenced. These guidelines stated that prisoners who had exercised good conduct were normally recommended for parole after serving a third of their sentence. The Home Secretary later changed these guidelines. The same was true in Hargreaves. Nor, in contrast to the situation in Hamble Fisheries, could the prisoners in Findlay or in Hargreaves be said to have relied on this policy to their detriment. ${ }^{25}$ In Coughlan, however, the promise that Mardon House would be a home for life was "confined to one person or a few people, giving the promise or representation the character of a contract". ${ }^{26}$ The applicants were not merely relying on a general policy or set of guidelines.

Third, both Findlay and Hargreaves and Coughlan could be regarded as examples of substantive legitimate expectations, with the former having a less stringent form of review than the latter. In cases like Findlay and Hargreaves the court will only ensure that a public authority takes a substantive legitimate expectation into account, when this amounts to a relevant consideration. Moreover, the court will check to ensure that a public authority gave the appropriate weight to that legitimate expectation, applying the Wednesbury standard of review. In cases like Coughlan, however, the court provides a much more stringent form of review, applying a test

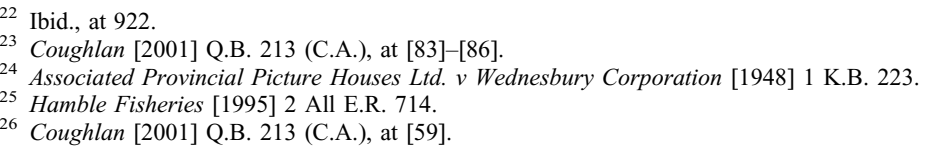


of abuse of power. Moreover, "the court will have the task of weighing the requirements of fairness against any overriding interest relied upon for the change of policy". ${ }^{27}$ This goes beyond the more limited form of scrutiny in Wednesbury.

Later case law immediately following Coughlan failed to provide further clarification. Laws L.J. remarked in Begbie, for example, that the first and the third categories of legitimate expectation set out in Coughlan "are not hermetically sealed" and the classification of a particular case will often depend upon "the facts of the case, viewed always in their statutory context". ${ }^{28}$ The later Court of Appeal decision in Bibi provides a further illustration of fluidity. ${ }^{29}$ Understanding this to be their statutory duty, the council promised Bibi and his family, who were homeless, that they would have permanent accommodation within 18 months. However, when it became clear that the council only had a legal duty to prioritise the homeless when allocating secure but not permanent accommodation, the council reneged on its promise. Bibi argued that this breached his substantive legitimate expectation. The Court of Appeal agreed that the council had created a substantive legitimate expectation that Bibi would be provided with permanent accommodation. However, rather than concluding that the council should provide Bibi with accommodation in line with the legitimate expectation it had generated, the court directed that the council had to take Bibi's substantive legitimate expectation into account when allocating permanent housing.

Rather like the distinctions between Findlay and Hargreaves and Coughlan, it is possible to analyse Bibi as an example of a category three substantive legitimate expectations case, but where there were good reasons for applying a less stringent standard of review. The promise made to Bibi was clear and was made to a specific individual. It was not a general policy applied to a wide range of individuals. Nevertheless, a less stringent standard of review should apply here. If the court were to conclude that the next suitable permanent accommodation should be granted to Bibi and his family, as there were no good public policy reasons to resile from this representation, this would effectively substitute the court's assessment of housing allocation decisions for that of the council. As such, the better way of protecting the substantive legitimate expectation, to ensure there was no abuse of power by the council, would be to require the council continually to consider the promise of permanent accommodation made to Bibi whenever the council was deciding how to allocate permanent accommodation.

27 Coughlan [2001] Q.B. 213 (CA), at [57].

${ }^{28}$ R. v Secretary of State for Education and Employment, ex parte Begbie [2000] 1 W.L.R. 1115, 1130.

${ }^{29}$ R. (Bibi) v Newham London Borough Council [2001] EWCA Civ 607, [2002] 1 W.L.R. 237. 
However, it is also possible to analyse Bibi as falling within the first category established by Coughlan. After all, the court only provided the same amount of protection to the expectation in Bibi as set out in a category one case - where the legitimate expectation is a relevant consideration. Although Bibi appears to be a case of substantive legitimate expectations, is this really a case, like Hargreaves and Findlay, where all it was reasonably legitimate for Bibi to expect would be that he and his family would be allocated permanent accommodation when they were the most deserving family to receive a permanent home when one became available?

Case law decided shortly after Coughlan also illustrates how confusion can also arise between the second and the third category of legitimate expectations. Procedural legitimate expectations arise when an individual has an expectation of a particular process. A substantive legitimate expectation may arise when an individual has an expectation of a particular outcome. In addition, a secondary procedural legitimate expectation may be created where an individual has an expectation of a substantive outcome, but this is protected through the provision of a particular procedure rather than a specific outcome. ${ }^{30}$ This normally arises when an individual has relied on a policy as opposed to a specific representation in order to support that individual's legal claim to a substantive legitimate expectation. In Niazi/Bhatt Murphy, Laws L.J. argued that a secondary procedural legitimate expectation would normally take the form of representations or consultation, depending on the circumstances. For Sedley L.J., there would be a requirement of transitional measures from the old to the new policy, which may be satisfied in some cases merely by informing individuals of a forthcoming change in policy.

In addition to these doctrinal difficulties, further uncertainty arose as to the principles underpinning the protection of substantive legitimate expectations and the judicial approach that should be adopted by the courts when determining substantive legitimate expectations cases. In his original article, Forsyth identified Vertrauenschutz - the protection of promises - as the key principle underpinning legitimate expectations. ${ }^{31}$ This approach is reflected in Coughlan. Category three cases, which receive the strongest form of protection, are those where the promise argument is the strongest. A public body has made a specific promise to an individual or group of individuals, creating a more precise bond of trust between the public administration and the individual. The same is not true in category one cases, where either trust has not been breached on the facts, or where there is reliance on a general policy as opposed to a specific representation or promise.

${ }^{30} R$. (on the application of Bhatt Murphy (a firm) and others) $v$ Independent Assessor; $R$. (on the application of Niazi and others) $v$ Secretary of State [2008] EWCA Civ 755, (2008) 152(29) S.J.L.B. 29.

${ }^{31}$ Forsyth, "The Provenance and Protection of Legitimate Expectations", 241-45. 
A different foundation for substantive legitimate expectations was provided in later case law. In Nadarajah, Laws L.J. explained that both procedural and substantive legitimate expectations are "grounded in fairness", although he preferred to express this as "a requirement of good administration, by which public bodies ought to deal straightforwardly and consistently with the public".32 Fairness runs through all three categories of legitimate expectation set out in Coughlan. In category two cases, where the court determines that a representation or a practice gives rise to a procedural legitimate expectation, from which a public body then resiles, "the court itself will judge the adequacy of the reasons advanced for the change of policy, taking into account what fairness requires". ${ }^{33}$ Again, in category three cases, "once the legitimacy of the expectation is established, the court will have the task of weighing the requirements of fairness against any overriding interest relied upon for the change of policy". ${ }^{34}$

These divergent foundations also give rise to distinct judicial approaches when determining substantive legitimate expectations cases. I will describe the approach taken by the court in Coughlan as doctrinal. The Court of Appeal analysed previous case law to devise a series of categories that could be used to classify different types of legitimate expectation, as well as providing an account of the legal consequences that apply to each of these classifications. In Nadarajah, however, Laws L.J. adopted another approach. Rather than examining previous case law to determine specific categories of legitimate expectations, Laws L.J. drew on previous case law to establish the principle underpinning the protection of legitimate expectations: "Where a public authority has issued a promise or adopted a practice which represents how it proposes to act in a given area, the law will require the promise or practice to be honoured unless there is good reason not to do so." 35

This is very similar to Forsyth's account of Vertrauenschutz. Similarly, Laws L.J. regarded this principle as applying equally to procedural and substantive legitimate expectations. However, unlike Forsyth's approach, Laws L.J. applied a test of proportionality to determine whether the public body could resile from its promise, taking into account the respective force of relevant interests. ${ }^{36}$ Consequently, for Laws L.J., "where the representation relied on amounts to an unambiguous promise; where there is detrimental reliance; where the promise is made to an individual or specific group", then it will be harder to conclude that resiling from the promise is proportionate. ${ }^{37}$ However, it is more likely to be proportionate to resile from a

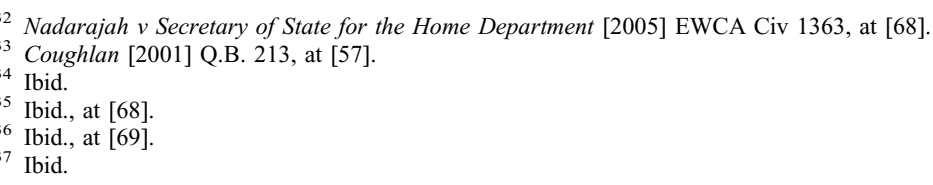


substantive legitimate expectation "where the government decision-maker is concerned to raise wide-ranging or "macro-political" issues of policy". 38

This approach is further distinguished from that in Coughlan and subsequent case law applying Coughlan as it collapses the distinction between factors affecting whether a substantive legitimate expectation has been created and whether that substantive legitimate expectation falls into a Coughlan category three substantive legitimate expectation, from an assessment of whether there are good reasons for a public body to resile from a legitimate expectation. Furthermore, Laws L.J. states that these considerations are merely "pointers not rules", recognising that the balance between these competing interests "is not precisely calculable, its measurement not exact". ${ }^{39}$ I will describe this approach as adopting a principled as opposed to a doctrinal approach to legitimate expectations.

This brief examination would appear to suggest that Forsyth was right to be concerned about the potential proliferation of case law on substantive legitimate expectations and the possible collapse of this newly formed head of review into an "inchoate justification for judicial intervention". 40 This collapse would appear to have taken place in two ways. First, as concerns the classification of substantive legitimate expectations and its delineation from other heads of judicial review and, second, as concerns the theoretical justifications for legitimate expectations and the approach to judicial reasoning deployed in the case law. The following section will explain how more recent case law has provided some clarity as regards the first of these issues, particularly as regards the establishment of a core case of substantive legitimate expectations.

\section{The Core Case of Substantive Legitimate Expectations}

The core case of substantive legitimate expectations stems from the third category of legitimate expectations set out in Coughlan. A core case has three components, relating to: (1) the nature of the representation; (2) the test used to assess whether a public body can resile from that representation; and (3) the burden of proof. Courts also adopt a doctrinal approach when determining core cases.

In Finucane, Lord Kerr set out the core case of substantive legitimate expectations as follows: "where a clear and unambiguous undertaking has been made, the authority giving the undertaking will not be allowed to depart from it unless it is shown that it is fair to do so."41

\footnotetext{
${ }^{38}$ Ibid.

39 Ibid.

${ }^{40}$ Forsyth, "Legitimate Expectations Revisited", 429.

41 In the matter of the application of Geraldine Finucane for Judicial Review (Northern Ireland) [2019] UKSC 7, at [62].
} 
First, a core case of substantive legitimate expectations occurs when a public body makes a specific representation that is clear and unambiguous and is also devoid of any qualification. ${ }^{42}$ Second, courts will, normally, apply a test of proportionality to determine whether it is an abuse of power for the public body to resile from a legitimate expectation. However, the stringency with which the test of proportionality is applied varies, depending on the nature of the circumstances before the court. Third, it is for the applicant to show that a public body's actions created a substantive legitimate expectation. It is then, normally, for the public body to demonstrate that there are good reasons to resile from this representation.

However, even the above brief account of the core case of substantive legitimate expectations is insufficiently precise, as is demonstrated by the use of the word "normally". In order to understand the core case further, we need to draw distinctions between different types of situation in which a substantive legitimate expectation may be said to arise. Craig provides four examples. First, an individual may rely on a general norm or policy, which is then replaced by a later norm or policy. Second, a general norm or policy may not be applied to a particular individual. Third, a public body may have made a representation to a particular individual, from which it later seeks to resile because of a change in policy. Fourth, a public body may make a representation, which an individual relies upon, but the public body later resiles from the specific representation for reasons other than a general change of policy. ${ }^{43}$ The core case of a substantive legitimate expectation arises in the third and fourth instances, where a specific representation has been made. It may be easier for a public authority to justify resiling from a legitimate expectation in the third instance.

Craig's first example does not fall within the core case of a substantive legitimate expectation. In Niazi/Bhatt Murphy, both Sedley and Laws L.JJ. stated that the mere existence of a general policy that applied to the applicant, which is later changed, will not in and of itself give rise to a substantive legitimate expectation that falls into the third category of Coughlan. ${ }^{44}$ However, policies may create a substantive legitimate expectation where they include statements that the policy is likely to continue into the future, for example if there was a standstill provision in the policy, or the policy implemented international law that provided permanent guarantees. ${ }^{45}$ Outside of these specific circumstances, an individual may be able to

\footnotetext{
${ }^{42}$ R. v Board of Inland Revenue, ex parte MFK Underwriting Agencies Ltd. [1990] 1 W.L.R. 1545.

43 P.P. Craig, Administrative Law, 8th ed. (London 2016), 671-72.

44 Bhatt Murphy; Niazi [2008] EWCA Civ 755.

${ }^{45}$ See R. (Turkish Alliance) v Secretary of State for the Home Department [2020] EWCA Civ 553, [2020] 1 W.L.R. 2436, although there was insufficient evidence of this on the facts, a standstill clause being insufficient evidence of the permanent application of this policy.
} 
indirectly protect his substantive expectation through a secondary procedural legitimate expectation.

A secondary procedural legitimate expectation may include, for example, a right of consultation before a change in policy, or the right to be notified of a change in policy. However, this is not automatically generated whenever a policy is changed. ${ }^{46}$ Instead, further evidence is required: for example, where a specific representation is made to an individual that a general policy will be applied to that individual, or where a body provides specific assurances that individuals would be consulted before a change of policy. As Luton Borough Council demonstrates, it can be difficult to establish sufficient evidence of a right to consultation, even when there has been detrimental reliance on a policy and communication between the applicant and the public body concerning the application of the policy to that individual. ${ }^{47}$ It can be easier, however, to establish a procedural legitimate expectation of consultation from past practice, providing there is sufficient consistent evidence of this practice. ${ }^{48}$

Case law after Coughlan also demonstrates that Craig's second example - where a general policy is not applied to a specific individual - is not part of the core case of a substantive legitimate expectation. Rather, it is a freestanding principle of consistent application of policy; public authorities must apply a general policy to an individual falling within that policy unless there are good reasons not to do so. ${ }^{49}$ This new principle was developed following the difficulty of classifying these cases as ones of substantive legitimate expectations. It can be hard to see an individual having a legitimate expectation that a general policy would be applied to her when she was not even aware of the policy. ${ }^{50}$

Further case law has clarified further elements of a core case of substantive legitimate expectations. Prior to the decision in Finucane, problems arose as to whether an individual had to rely detrimentally on a substantive legitimate expectation for it to be protected by English law. Although statements in decisions in the Court of Appeal had suggested that detrimental reliance was not necessary, ${ }^{51}$ Lord Carnwath in United Policyholders Group v Attorney General of Trinidad and Tobago appeared to suggest

46 See R. (Delve) v Secretary of State for Work and Pensions [2020] EWCA Civ 1199, [2020] H.R.L.R. 20, concerning whether there was a right to notify women of a change in the age at which they qualified for the state pension.

47 R. (Luton Borough Council) v Secretary of State for Education [2011] EWHC 217 (Admin), [2011] Eq. L.R. 481

48 R. (Article 39) v Secretary of State for Education [2020] EWCA Civ 1577, [2021] P.T.S.R. 696; R. (on the application of MP) $v$ Secretary of State for Health and Social Care [2020] EWCA Civ 1634.

49 Mandalia $v$ Secretary of State for the Home Department [2015] UKSC 59, [2015] 1 W.L.R. 4546.

50 See e.g. R. (on the application of Lumba) v Secretary of State for the Home Department [2011] UKSC 12, [2012] 1 A.C. 245, R. (on the application of Rashid) $v$ Secretary of State for the Home Department [2005] EWCA Civ 744, [2005] Imm. A.R. 608 and Nadarajah [2005] EWCA Civ 1363.

51 Nadarajah [2005] EWCA Civ 1363. 
that detrimental reliance was a necessary requirement. ${ }^{52}$ However, as Lord Kerr clarified in Finucane, Lord Carnwath's statement was only obiter. Moreover, Lord Kerr stated in Finucane that detrimental reliance was not a necessary component of a core case of substantive legitimate expectations - although he was unwilling to definitively determine this issue as it was not relevant on the facts of the case. ${ }^{53}$ Lord Carnwath made it clear in Finucane that his statement in United Policyholders was meant only to apply to cases of substantive legitimate expectations, and not to procedural legitimate expectations or to the principle of the consistent application of policy established in Mandalia. He also clarified that he was now of the opinion that detrimental reliance was not a necessary component of establishing a substantive legitimate expectation, although it could be relevant when determining whether a public body should be able to resile from its legitimate expectation. ${ }^{54}$ This interpretation is a better fit with the case law prior to United Policyholders and has been followed in subsequent Court of Appeal decisions. 55

In addition, recent decisions in the Court of Appeal appear to suggest that a substantive legitimate expectation may arise from past practice. In $R$. (MP) $v$ Secretary of State for Health and Social Care, the most recent decision of the Court of Appeal to consider this issue, Newry L.J. clarified that a practice must be tantamount to a clear and unambiguous representation, that is devoid of qualification, if it is to create a substantive legitimate expectation. ${ }^{56}$ Although this is only obiter, the case itself, concerning a procedural as opposed to a substantive legitimate expectation, is likely to be followed in future cases. There is now a series of decisions in the Court of Appeal which include similar obiter dicta. Moreover, the recognition of a substantive legitimate expectation in this manner would fit with our understanding of the core case. The substantive legitimate expectation arises in representation cases where there is a specific representation to a small group, with its needing to be sufficiently clear and precise so as to determine the content of the representation. The same reason for protecting promises and trust in the administration in these circumstances would arise were this clear and precise promise to a small group of individuals to arise from evidence of past practice as well as through the means of a specific

52 United Policyholders Group v Attorney General of Trinidad and Tobago [2016] UKPC 17, [2016] 1 W.L.R. 3383.

${ }^{53}$ Ibid., at [72].

${ }^{54}$ Ibid., at [158]-[160].

55 See R. (Aozora GMAC Investment Ltd.) v Revenue and Customs [2019] EWCA Civ 1643, [2020] 1 All. E.R. 803, at [44]-[45]. See also J. Bell, "The Privy Council and the Doctrine of Legitimate Expectations Meet Again" [2016] C.L.J. 449 and J. Tomlinson, "The Narrow Approach to Substantive Legitimate Expectations and the Trend of Modern Authority" (2017) Oxford University Commonwealth Law Journal 75 .

${ }^{56} M P$ [2020] EWCA Civ 1634, at [51]-[53]. See also R. (on the application of Heathrow Hub Ltd.) $v$ Secretary of State for Transport [2020] EWCA Civ 213, [2020] 4 C.M.L.R. 17 and Article 39 [2020] EWCA Civ 1577. 
representation. The only difference between the two would appear to be evidential.

In addition to clarifying the nature of the representation required to establish a substantive legitimate expectation that would fall into the third category of cases in Coughlan, later case law has also established that the test used by the court to determine whether a public body can resile from a legitimate expectation is, normally, proportionality. ${ }^{57}$ However, as in other situations where a proportionality test is applied, a range of factors may influence the stringency of this test. For example, the proportionality test is applied less stringently when the case concerns political or macroeconomic issues. ${ }^{58}$

What is less clear, however, is whether the burden of proof moves from the applicant to the public body to demonstrate sufficiently strong reasons of public policy to justify the public body's resiling from a legitimate expectation. In Paponette, the Privy Council concluded that the burden of proof rested with the public body, albeit in this case no reasons for resiling from the representation had been provided. This allocation of the burden of proof is the most consistent pattern in later case law. However, in Aozora, Rose L.J. suggested that this was not the case, as the issue of whether a public body could resile from a promise was all part and parcel of the claim brought by the applicant to be able to receive the substantive benefit formed by the substantive legitimate expectation. ${ }^{59}$

This clarification of the core case of substantive legitimate expectations does help to resolve some of the problems that arise when determining when a legitimate expectation will fall into the third category of Coughlan, distinguishing this from the first category of Coughlan, where the substantive legitimate expectation is only protected either as a relevant consideration or through an application of Wednesbury unreasonableness. This understanding of the core case of substantive legitimate expectations also helps to clarify some of the vagueness in the early case law adumbrated in the previous section. It would suggest that Hargreaves and Findlay did not fall within the third category of cases in Coughlan as they were not sufficiently clear, precise and unconditional specific representations to a small group of individuals. However, it does not clarify how best to categorise Bibi. Although the representation was sufficiently clear and precise and made to a specific individual, the court protected the substantive legitimate expectation by requiring the council to consider this as a relevant

${ }^{57}$ Nadarajah [2005] EWCA Civ 1363, Heathrow Hub [2020] EWCA Civ 213, Paponette v Attorney General of Trinidad and Tobago [2010] UKPC 32, [2012] 1 A.C. 1, and Finucane [2019] UKSC 7.

${ }^{58}$ See Begbie [2000] 1 W.L.R. 1115 with regard to macro-political issues and Bibi [2001] EWCA Civ 607 on macro-economic issues. See also M. Elliott, "From Heresy to Orthodoxy: Substantive Legitimate Expectations in the United Kingdom" in M. Groves and G. Weeks (eds.), Legitimate Expectations in the Common Law World (Oxford and Portland 2017), 217.

59 Aozora v Revenue and Customs [2019] EWCA Civ 1643, at [46]. 
consideration each time the council determined the allocation of permanent housing. This is not the normal way in which a court would weaken the stringency of the proportionality test. Consequently, it may be easier to categorise this case as one where, despite the representation being sufficiently clear and precise, it was not unconditional. The promise of a permanent home was dependent upon there not being other individuals who were more deserving of a permanent home.

Whilst there is evidence in the case law to support the existence of a core case of substantive legitimate expectations, nevertheless there are still cases which approach substantive legitimate expectations in a different manner. Whilst the courts adopt a doctrinal approach when analysing the core case of legitimate expectations, they adopt a more principled approach in other cases where the doctrine of legitimate expectations is applied outside of this core case. It is to these examples that we will turn in the next section.

\section{Beyond the CoRe: A Principled Approach}

The core case occurs in only one of the four situations described by Craig in which a substantive legitimate expectation may be created. In other situations, the courts have either developed a head of review to achieve the right balance between certainty and legality or have relied on this balance being achieved through the application of Wednesbury, understood in its broad sense to include relevancy of consideration in addition to rationality. In these other situations, the courts have adopted a more principled as opposed to a doctrinal approach, drawing on general principles to determine whether to promote legal certainty, upholding an applicant's expectations, or to promote legality and preserve the discretionary power held by the public body whose actions created the legitimate expectation. This is normally analysed through the lens of fairness.

We saw, above, when analysing the judgment of Laws L.J. in Nadarajah that Laws L.J. balanced a range of factors in order to determine whether a substantive legitimate expectation should be protected, or whether it was proportionate for the public authority to resile from this representation. In determining this issue, factors that would be relevant to determining whether the representation created a substantive legitimate expectation of the type that would be protected by the law, those that would influence whether the representation should be resiled from and those influencing the standard of review are all balanced at the same stage. ${ }^{60}$ It is this in the round analysis that distinguishes this more principled approach to judicial reasoning from the doctrinal approach favoured in core cases of substantive legitimate expectations. Moreover, all of these are used as

${ }^{60}$ Coughlan [2001] Q.B. 213, at [69]. 
"pointers not rules", providing further evidence of a more principled approach. 61

Nadarajah would now be categorised, not as a case of substantive legitimate expectations, but as an application of the general principle in Mandalia that policies should be applied consistently. Indeed, the Supreme Court cited Nadarajah in support of the free-standing principle of the consistent application of a lawful policy. ${ }^{62}$ The Supreme Court also referred to the principle, set out by Lord Dyson in Lumba, that "a decision-maker must follow his published policy ... unless there are good reasons for not doing so". ${ }^{63}$ In these cases, it is for the court both to determine the content of the policy in question, and to evaluate the reasons for not following this particular policy. ${ }^{64}$ Courts will also check that the policy in question was lawful and that it did not place too great a fetter on the discretion of the public body. Mandalia also illustrates that this principle applies equally to procedural and substantive legitimate expectations. In Mandalia, the applicant wished to rely on a policy of procedural discretion, where the immigration office would ask for further information to process a visa application, rather than refuse to grant a visa due to its failure to provide the requisite evidence to support the application.

As Nadarajah makes clear, this principle of ensuring a consistent application of a lawful policy is not just based on balancing legality and certainty. It also concerns issues of fairness. As Laws L.J. made clear in his judgment:

Where a public authority has issued a promise or adopted a practice which represents how it proposes to act in a given area, the law will require the promise or practice to be honoured unless there is good reason not to do so. What is the principle behind this proposition? It is not far to seek. It is said to be grounded in fairness, and no doubt in general terms that is so. I would prefer to express it rather more broadly as a requirement of good administration, by which public bodies ought to deal straightforwardly and consistently with the public. ${ }^{65}$

However, difficulties have arisen when drawing on fairness to underpin a protection of substantive legitimate expectations, as well as when using this to determine when a public body cannot resile from a policy. First, should this general principle of fairness apply to both substantive and procedural issues, or is this confined to issues of process? Second, how does this protection of fairness apply in practice, such that we can clearly determine the scope of its application and its delineation from other heads of

\footnotetext{
${ }^{61}$ Ibid.

${ }^{62}$ Mandalia [2015] UKSC 59, at [29].

${ }^{63}$ R. (Lumba) v Secretary of State for the Home Department [2011] UKSC 12, at [26].

${ }^{64}$ Mandalia [2015] UKSC 59, at [31].

${ }^{65}$ Nadarajah [2005] EWCA Civ 1363, at [68]. This was cited with approval in Mandalia [2015] UKSC 59, at [29].
} 
review? Whilst there is case law that has determined the first issue, problems still arise with regard to the second issue.

The Supreme Court ruled conclusively in Gallaher that there is no general substantive duty to act fairly in English administrative law. ${ }^{66}$ Lord Carnwath, giving the leading judgment of the Supreme Court, concluded that "fairness ... can readily be seen as a fundamental principle of democratic society; but not necessarily one directly translatable into a justiciable rule of law. Simple unfairness as such is not a ground for judicial review". 67 Instead, fairness is protected through specific heads of review. Procedural fairness is protected through the application of the principles of natural justice. Substantive fairness, however, is protected either by an application of legitimate expectations or irrationality - Wednesbury unreasonableness. ${ }^{68}$ Lord Sumption and Lord Briggs agreed. ${ }^{69}$

Despite this clarity, it can be difficult to delineate in practice between an aspect of procedural and an aspect of substantive fairness. What is clear is that providing an individual with a particular outcome, or a substantive benefit, is a substantive aspect of fairness. This can be contrasted with the provision of a particular procedure - for example a right to a fair hearing. In Gallaher, for example, the applicant had been arguing for substantive fairness as they wished to receive the same outcome as had been granted by the Office of Fair Trading (OFT) to another individual whom they believed to be in the same situation. However, it is difficult to know how courts distinguish between procedural and substantive fairness beyond these clear cases. This can be illustrated in particular in the recent Supreme Court decision in Pathan. ${ }^{70}$

Pathan, an Indian national, had a Tier 2 visa for limited leave to remain in the UK sponsored by his employer, Submania Ltd., who had the requisite licence to sponsor Tier 2 visa applications. After Pathan applied for the extension of his leave to remain in the UK, the Home Office investigated Submania. At the conclusion of the investigation, Submania's licence to sponsor visa applications was revoked. The Home Office did not inform Pathan that Submania's licence had been revoked. Three months later, Pathan was informed that his application to renew his Tier 2 visa had been refused. Pathan argued both that the Home Office should have informed him in a timely manner of their decision to cancel Submania's licence and that he should have been granted sufficient time to amend his visa application in the light of the refusal of his employer's licence to sponsor Tier 2 visa applications.

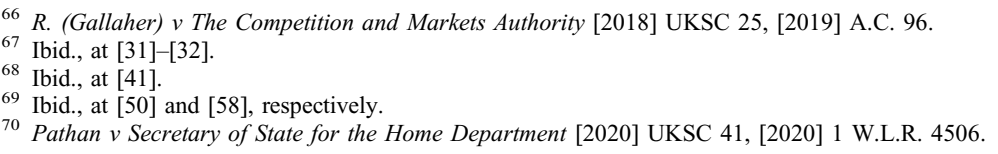


In a majority judgment, the Supreme Court held that the Home Office had breached procedural fairness by failing to inform Pathan of the Home Office's decision to remove Submania's sponsorship licence. However, the court was divided as to whether the duty to provide Pathan with more time to amend his visa application in the light of the loss of sponsorship was an aspect of procedural or substantive fairness. Lady Arden and Lord Wilson concluded that this was a substantive benefit flowing from an application of procedural fairness. The rest of the Supreme Court disagreed, regarding this, instead, as an aspect of substantive fairness. Consequently, whilst Pathan was successful in his argument that he should have been notified, he did not succeed in his claim for further time to remain in the UK in order to amend his visa application.

Lady Arden concluded that, although the provision of extra time to remain in the UK was a substantive right, this flowed from his procedural right to receive timely notification of the cancellation of his employer's sponsorship licence. There is no point in notifying Pathan of the revocation of his employer's licence if Pathan then has no time in which to take meaningful steps in the light of this information. To fail to notify Pathan promptly was a form of systemic failure, whose consequence was to deprive Pathan of the right he would otherwise have had to seek an alternative visa application in a timely manner so as to prevent his potential removal from the UK. Lord Kerr and Lady Black disagreed. They concluded that to require a requisite period to be granted to Pathan to remain in the UK in order to allow him to respond went beyond what was required by procedural fairness. It was, instead, a matter of substantive fairness. It went beyond the negative duty on a public body, requiring the administration to provide time for Pathan to respond. As a positive right, this was clearly substantive as opposed to procedural. Lord Briggs also concluded that the granting of a period of time to enable Pathan to respond to the revocation of his employer's licence was a matter of substantive as opposed to procedural fairness, but for different reasons. He distinguished between situations in which an applicant was given more time to put forward his best case based on the facts and one where the applicant was given extra time to improve the facts on which his case was based. The former was an aspect of procedural fairness; the latter, of substantive fairness. To provide Pathan with extra time crossed the line, becoming a matter of substantive fairness.

The division in Pathan illustrates the problems that can arise when the protection of procedural fairness may also give rise to substantive rights. A provision of timely notice of a decision that affects your rights may be useless in practice if this is unable to allow you to protect your substantive rights. Yet, at the same time, a right to remain in the UK is clearly substantive and distinct from the procedural right of notification. It can be easy to see, therefore, how a focus on balancing principles, or an assessment of 
fairness, can lead Forsyth to the conclusion that the law of substantive legitimate expectations could give rise to incoherence, as well as create the suspicion that a protection of substantive legitimate expectations - here through an application of the principle of the consistent application of policy - was merely performing a rhetorical role.

Difficulties of classification, however, do not merely arise when courts apply a more principled approach, drawing on conceptions of fairness or using a range of criteria to balance certainty and legality. For example, it can be difficult to distinguish examples of procedural legitimate expectations cases, falling into the second category of Coughlan, from applications of natural justice/the principle of procedural fairness. Forsyth, for example, recognised the problems that arise with classifying Schmidt v Secretary of State for Home Affairs as a case of procedural legitimate expectations, even though he traced the origins of the protection of procedural legitimate expectations to this case. $^{71}$ Here, following a change in policy, Scientology establishments were no longer recognised as valid educational organisations, and, therefore, the Minister refused to grant an extension to the visas of Schmidt and others, who had originally been given leave to enter the country to study at a Scientology establishment. One of the grounds of challenge was that the Minister should have provided the students with an opportunity to make representations as to why their extension should be granted.

In assessing this issue, Lord Denning argued that whether a student should have a right to make representations depended upon whether he had "some right or interest, or I would add, some legitimate expectation, of which it would not be fair to deprive him without hearing what he has to say". ${ }^{72}$ In particular, the students would have a right to make representations if their licences to remain had been revoked before they had expired..$^{73}$ However, this case is better understood as one where the court is using the existence of a legitimate expectation to determine the scope of the content of natural justice, or procedural fairness. The court is assessing whether the fact that an applicant expected to remain in the UK until the completion of his studies meant that he had a right to make representations should that expectation be removed. This is both because no specific representation was made to Schmidt and because the court did not determine the case by assessing whether there were good reasons for the Minister to resile from his earlier policy on which Schmidt had relied.

Similar problems continue to arise. For example, in Article 39, a legal challenge was brought by Article 39, an interest group designed to protect the rights of children, and the Children's Commissioner to regulations

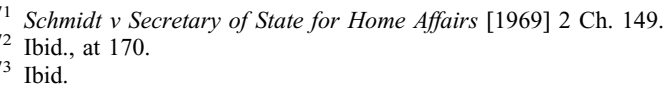


modifying the provision of children's services during the coronavirus pandemic. ${ }^{74}$ A duty of consultation arose because of the past practice of the Minister in consulting the Children's Commissioner and Article 39 and other public interest groups when enacting regulations that affected the provision of children's services. In addition, Article 39 and the Commissioner should have been consulted because, having chosen to consult those providing services to children, it would be contrary to the principles of procedural fairness not also to consult those, like the Commissioner and Article 39 , who represented those whose interests would be affected by the proposed reduction in services during the pandemic.

The more principled approach, therefore, may confirm Forsyth's suspicions that protecting substantive legitimate expectations may give rise to incoherence. However, in some instances the same may be said of the protection of procedural as well as substantive legitimate expectations. Moreover, some of these difficulties - for example the one arising in Pathan - may stem more from the problem of delineating between process and substance than that of determining the precise scope of the doctrine of legitimate expectations. The deeper question that arises, however, is whether the law should confine substantive legitimate expectations to the core case, or whether it should include these other peripheral cases where the courts develop a more principled approach. Furthermore, if we do consider these cases to be beyond the scope of substantive legitimate expectations, do they give rise to such incoherence that they should not be protected at all, save through an application of Wednesbury unreasonableness?

\section{Navigating the Crossroads}

Our exploration of the case law demonstrates a distinction between core cases of substantive legitimate expectations and other cases which share similar values, but which are now regarded as involving distinct principles. In these situations, there is a lack of clarity as to whether the doctrine of substantive legitimate expectations applies, and if so, the nature of the relevant remedy. It can be difficult to distinguish between situations in which the courts are applying the doctrine of substantive legitimate expectations and those where the courts are recognising that, because a substantive legitimate expectation has been created, it has become a relevant consideration that a public body must take into account when exercising its discretion. In addition, it can be hard to distinguish situations in which courts apply procedural fairness requirements to those who have a substantive legitimate expectation, as well as to distinguish between substantive and procedural fairness in practice.

${ }^{74}$ Article 39 [2020] EWCA Civ 1577. 
There are two paths that English administrative law could follow when seeking to clarify these uncertainties. First, the law could limit the head of review of substantive legitimate expectations to include only core cases, with other cases not being worthy of protection unless they fall under other heads of review that have been clearly established by earlier case law. Second, English law could embrace the wider principles underpinning all of the four situations set out by Craig in which we might expect a substantive legitimate expectation to be created and potentially protected, albeit to different degrees. The first path is more doctrinal in approach, whereas the second adopts a more principled approach.

It is clear from Forsyth's writing that he would take the first path, narrowing the application of substantive legitimate expectations to the core case. In his first article, Forsyth identified Vertrauenschutz as the key principle underpinning legitimate expectations. This protection of promises is a better fit for the core case of substantive legitimate expectations, with the broader principled approach focusing more on a general protection of fairness. In his later work, Forsyth argued that he found other justifications that had been used in the case law to justify substantive legitimate expectations to be unhelpful. Concepts such as abuse of power, good administration and fairness were too vague to provide any useful means of determining the scope and application of substantive legitimate expectations as a distinct head of judicial review. ${ }^{75}$ They could also, potentially, undermine the delicate balance between legal certainty and legality required in any protection of substantive legitimate expectations. Forsyth would therefore prefer to confine category three Coughlan cases to situations similar to that which arose on the facts of that case - where a representation is made to a small group in a situation that is almost akin to a contract. ${ }^{76}$

Forsyth is not alone in this view. Jason Varuhas has specifically argued in favour of confining substantive legitimate expectations to situations similar to the core case of substantive legitimate expectations: "the case where an authority makes an express promise, assurance or undertaking to an individual or group of individuals that the authority will act or omit to act in some way, this act or omission having a bearing on the individual or group's interests."77 Varuhas also argues that other instances where courts have discussed substantive legitimate expectations are extraneous. He would not include, for example, situations where an individual relied on a policy which was later changed, ${ }^{78}$ or situations where a policy was not applied to a specific individual, including those situations where a public body applied a secret rather than the published policy to an individual. ${ }^{79}$

\footnotetext{
Forsyth, "Legitimate Expectations Revisited", 431.

76 Ibid., at 436-38.

77 J.N.E. Varuhas, "In Search of a Doctrine: Mapping the Law of Legitimate Expectations" in Groves and Weeks (eds.), Legitimate Expectations in the Common Law World, 17, 40.

78 Ibid., at 20-29.
} 
In addition to confining substantive legitimate expectations to the core case, Varuhas also advocates that courts adopt a more structured test, drawing on the criteria set out in R. v Jockey Club, ex parte RAM Racecourses Ltd..$^{80}$ Varuhas sets out a six-point test as follows:

1. Was the representation clear and unambiguous?

2. Was the representation made directly to the claimant or, if not, was the claimant within the class of persons who were entitled to rely, or was it reasonable for the claimant to rely, on the representation?

3. Did the claimant rely?

4. Did the claimant suffer detriment in consequence of reliance?

5. Can the defendant show that overriding public interests entitled it to depart from its promise?

6. Ought the court to exercise its remedial discretion in favour of the claimant? ? $^{81}$

It is for the claimant to satisfy the first four criteria, with the defendant carrying the burden of proof as to there being good reasons for the public body to resile from this substantive legitimate expectation.

Varuhas prefers a more structured approach, first, because he fears that otherwise judges may apply an intuitive approach. This should be avoided as it is the role of the court to apply the law, not to decide cases intuitively. Second, Varuhas is concerned that failing to confine substantive legitimate expectations to the core case, applying a structured approach, could lead to the courts applying substantive legitimate expectations too broadly, creating incoherence. He is also concerned that any other approach would merge substantive legitimate expectations with other heads of review. Although he recognises that this may mean that the law is insufficiently flexible, he argues that there is sufficient flexibility in the core case to allow the law to develop when required. Moreover, he argues that, in most of the situations where substantive legitimate expectations have strayed beyond the core case, other heads of review were available to protect the interests of the applicant.

Paul Daly's work provides an example of adopting the second path. ${ }^{82} \mathrm{He}$ develops a pluralist account of legitimate expectations, which he regards as applying equally to procedural and substantive legitimate expectations. For Daly, there is a common thread running through all legitimate expectation cases: "a legally cognisable interest engendered by official action at Time X which is defeated by official action at Time Y". ${ }^{83} \mathrm{He}$ recognises a plethora

\footnotetext{
Ibid., at 29-34.

[1993] 2 All. E.R. 225.

1 Varuhas, "In Search of a Doctrine", 46-47.

82 P. Daly, "A Pluralist Account of Deference and Legitimate Expectations" in Groves and Weeks (eds.), Legitimate Expectations in the Common Law World, 101.

83 Ibid., at 110.
} 
of values underpinning the protection of legitimate expectations: the prevention of an abuse of power; good administration; and the protection of the rule of law through upholding the dignity and autonomy of individuals. ${ }^{84}$ When applying these principles to protect substantive legitimate expectations, courts also need to be aware of two general principles that operate in the background of judicial review as a whole: the protection of democracy and the separation of powers. Courts should be aware of legislation which may prevent the protection of a legitimate expectation. Courts must also be wary of substituting their assessment of policy choices for those of the executive when assessing whether there are good reasons for a public body to resile from a legitimate expectation. ${ }^{85}$

Daly's approach is pluralist as he argues that there is no clear hierarchy between the values that can justify the protection of a legitimate expectation. Instead, the values need to be balanced and reconciled in each individual case. The application of these values and the outcome of an application for judicial review to protect a substantive legitimate expectation are both highly factually specific. Daly recognises that this requires courts to adopt a normative approach, similar to the one adopted by Laws L.J. in Nadarajah. ${ }^{86}$ Substantive legitimate expectations should not be confined to the core case. Instead, we should regard the core case as one specific situation in which the values underpinning the protection of legitimate expectations would be protected on the facts of the case. To approach the case law in this manner would remove the need to determine whether Mandalia was a distinct principle of legitimate expectations. Nor would difficulties arise as regards the application of Gallaher, which confines fairness in English law to procedural as opposed to substantive issues. Rather, Gallaher could be explained as a case in which there were good reasons not to apply the representation made to one party to other distinct parties.

English law appears to be stuck at a crossroads, choosing either to follow Forsyth and Varuhas, confining the scope of substantive legitimate expectations and adopting a doctrinal approach, or taking the path advocated by Daly, using a principled approach, where substantive legitimate expectations create values that may be protected in a variety of means through English law. However, I would argue that English law is not faced with such a stark choice. Instead, it is important to recognise that these two paths are complementary. Moreover, they reflect different aims and purposes of administrative law. Whilst the first path focuses on administrative law as a means of protecting individual rights from erosion by public bodies, the second recognises that administrative law can also facilitate good

\footnotetext{
84 Ibid., at $104-08$.

85 Ibid., at $108-10$.

86 Ibid., at $110-12$.
} 
administration and provide a safety valve to prevent administrative actions from eroding fundamental constitutional principles.

When analysing the two possible divergent paths, we have seen how the difference between the two paths is not just confined to whether English law provides a broader or a narrower protection of substantive legitimate expectations. The two paths also adopt distinct approaches to judicial reasoning. The narrow path prefers a doctrinal approach to legal reasoning rather than a principled approach. Analysing the differences in judicial reasoning provides a better means of evaluating the two competing paths for two reasons. First, the difference appears to turn on competing conceptual definitions of substantive legitimate expectations. Whilst Varuhas defines legitimate expectations narrowly, Daly advocates a broader definition which could include a wider range of cases falling within the scope of legitimate expectations. However, it is difficult to determine criteria that can be used to choose between competing conceptions, especially when this cannot be resolved by empirical data and turns more on whether to adopt a more or less abstract view of the concept of substantive legitimate expectations. ${ }^{87}$

Second, to decide between the two paths according to a preference for one or other of the competing conceptions of substantive legitimate expectations may be difficult to make as both paths may give rise to the same outcomes in practice. For example, confining substantive legitimate expectations to the core case, as advocated in taking the first path, would classify Mandalia and Nadarajah as falling outside of substantive legitimate expectations. The second path would include both within a broad principle of substantive legitimate expectations based on fairness and other values. However, the outcome would appear to be the same, regardless of which path is chosen. This is because the law has developed a further legal doctrine that provides protection for legal certainty, the consistent application of a lawful policy.

A better means of choosing between the two paths is through comparing and contrasting their different approaches to judicial reasoning, with the first path adopting a more doctrinal and the second a more principled approach. ${ }^{88}$ One possible reason for choosing the first path and a doctrinal approach is that this approach is less likely to give rise to judicial activism than adopting a principled approach. A preference to reduce potential judicial activism underpins Varuhas's preference for the first path. According to Varuhas, if courts adopt a more principled approach, this could give rise to judicial activism, with courts adopting an intuitive approach to decision-

${ }^{87}$ B. Bix, Jurisprudence: Theory and Context, 6th ed. (Durham, NC 2012), 18, and C. Roederer, "Negotiating the Jurisprudential Terrain: A Model Theoretic Approach to Legal Theory" (2003) 37 Seattle University Law Review 385, 422-25.

88 A.L. Young, "Lord Hoffmann and Public Law: TV Dinner or Dining at the Savoy?" in P.S. Davies and J. Pila (eds.), The Jurisprudence of Lord Hoffmann (Oxford and Portland 2015), 115. 
making as opposed to applying the law. A similar concern is shared by Forsyth.

Whilst it is true that adopting a doctrinal approach in a specific case prevents courts from taking intuitive decisions on the case before them, this does not provide a definitive argument in favour of English law restricting the scope of application of substantive legitimate expectations. First, there may still exist other situations in which courts adopt a principled approach. Second, the common law will continue to develop and, as was the case with the development of substantive legitimate expectations in Coughlan and the principle of consistent application of policy in Mandalia, courts will still have to decide when there is sufficient support in earlier case law to develop a new head of judicial review. Both Coughlan and Mandalia could have been criticised as exercises of judicial activism, yet the application of these decisions in future cases would be an example of a doctrinal approach. Third, the distinction between a doctrinal and a principled approach is a matter of degree. It is not true that, when adopting a principled approach, courts merely decide intuitively. Past case law is also often used to justify the existence of principles running through the common law. ${ }^{89}$

If we are to justify a preference for either a narrow doctrinal or a broad principled approach to substantive legitimate expectations, we need to analyse further consequences of these distinct forms of judicial reasoning. The doctrinal and purposive approaches are similar to rule-based and particularistic decision-making, as explained by Frederick Schauer. ${ }^{90}$ A doctrinal approach, like a rule-based approach, focuses on applying rules to a specific situation. Particularistic decision-making, in a similar manner to a principled approach, focuses on reasoning from first principles to reach the right outcome, rather than applying rules. There are three differences between the two approaches. First, a rule-based approach is more likely to create legal certainty and clarity. In contrast, although a principled approach may be less certain, with its application to a particular case being harder to predict, it may be more likely to reach the right outcome. Rules make generalisations. Consequently, there may be particular facts or circumstances about an individual applicant that would be overlooked when applying a rule-based approach.

Second, a rule-based approach is more likely to facilitate formal equality, whereas a particularistic approach is more likely to facilitate substantive equality. When applying a rules-based approach, those falling into the same category of rule receive the same outcome. However, this may give

89 A.L. Young, "Public Law Cases and the Common Law: A Unique Relationship?" in E. Fisher, J. King and A.L. Young (eds.), The Foundation and Futures of Public Law (Oxford 2020), 83.

${ }^{90}$ F. Schauer, Playing by the Rules: A Philosophical Examination of Rule-based Decision Making in Law and in Life (Oxford 1991), 77-78. 
rise to inequalities when we assess how the principles underpinning the rules would apply to similar individuals. Whilst like cases may be treated alike, this may mean that some of those who deserve to have their substantive legitimate expectation protected receive no legal protection. In this sense, the law is treating them differently from those who fall within the current rules. For example, to provide a protection for an individual in a similar situation to that of Mandalia, who was unaware of the policy that should have been applied to him, favours formal equality as his situation is distinct from that which arose in Coughlan where a specific individual was aware of the representation made to her of a particular outcome. Yet to confine legitimate expectations in this manner undermines substantive equality. Good administration and trust in the administration would be undermined both by failing to uphold a promise where there was no good reason not to do so and by failing to apply a policy to an individual where there was no justification not to do so.

Third, the different approaches distribute more or less autonomy to administrative decision-makers and rule-makers. A rule-based approach places relatively more power in the hands of the organisation making the rules, rather than the organisation applying the rules. A principled-based approach places more power in the hands of the organisation applying the principles, with a smaller role being played by the institution developing the principles. These distinctions are normally applied to situations in which the institutions inventing and applying the rules are distinct, for example when distinguishing between situations in which a legislature provides an administrator with a clear set of rules to apply, or with a broad discretion as to when an individual should receive a specific benefit. An administrator has more autonomy when they are given a discretionary power then when they are merely required to apply a set of clear rules established by the legislature.

This distinction applies differently when it is applied to choosing between different forms of legal reasoning. Courts both develop the rules, through developing common law heads of judicial review, and apply them to specific situations when they adjudicate in a particular case. Nevertheless, this distinction still has relevance. In the field of substantive legitimate expectations, for example, adopting a doctrinal rule-based approach provides greater certainty to public bodies, particularly when they make representations. Public bodies are aware of the test that courts will apply, realising that in situations when they make a clear, unambiguous and unconditional representation to an individual or clearly identified group of individuals, courts will require a public body to adhere to that representation, unless the public body can demonstrate clear overriding reasons of public policy to justify resiling from that representation. When developing policies, independently from specific representations, public bodies know they enjoy more freedom to change policy. However, if the doctrine of 
legitimate expectations is confined to core cases, it is harder to ensure that situations do not arise where, although formal equality is upheld, substantive equality is undermined and individuals whose rights should be protected fail to receive the protection they need. Varuhas argues that these cases may be picked up by other heads of review. However, this may not be the case. Moreover, even if this is the case, this may give rise to further confusion in the law, as illustrated above as regards the case law that arose immediately after Coughlan. Further, it may not facilitate substantive equality as the right principles underpinning the broad range of legitimate expectations are, at best, applied indirectly and, at worst, are not applied at all.

This balance is reversed when courts adopt a principled or particularised decision-making approach. Such an approach favours substantive equality. Courts consider general principles of substantive equality, public trust in the administration, and principles of good administration, assessing whether this would be upheld were a public body to resile from a particular policy, or fail to apply a lawful policy to a specific individual. This comes at the cost of certainty and predictability. It also gives relatively more decisionmaking power to the courts, determining how general principles apply to particular situations, although this would not require them to decide these issues intuitively. Courts would be applying principles of the common law when determining these cases.

These differences would appear to suggest that the choice between the two paths depends on a preference for formal or substantive equality: between legal certainty and ensuring the right outcome in particular cases. However, I would argue that English law needs both approaches to substantive legitimate expectations. This is because it is not the sole purpose of administrative law to protect individual rights from unlawful intrusion by public bodies. Nor are the purposes of administrative law limited to the protection of rights and the facilitation of good administration. Administrative law also performs a safety valve function. This provides a means of protecting fundamental rights and principles which underpin and run through the UK constitution. The principle of legality, as well as the general presumption against ouster clauses, may be understood in this manner. The principle of legality provides a means of ensuring fundamental constitutional principles are not accidentally eroded by legislation. The general presumption against ouster clauses upholds the rule of law, helping to maintain checks and balances between Parliament, the Government and the courts.

Adopting a doctrinal approach for core cases of substantive legitimate expectations provides legal certainty and facilitates good administration. Individuals have a clear understanding of when they will be able to rely on a specific promise or representation, facilitating their trust in the administration. Public bodies have greater certainty as to when their representation or past practice will give rise to a legally enforceable substantive 
legitimate expectation. This facilitates good administration. However, restricting substantive legitimate expectations to the core case may give rise to situations in which the values of legal certainty and good administration undermine substantive equality. In these situations, an application of a principled approach is justified. This enables administrative law to perform its other purposes, ensuring that administrative decision-making does not undermine fundamental values, ensuring that both the rule of law and principles of substantive equality are protected. A principled approach is more justified when courts are using administrative law as a constitutional safeguard, a fail-safe mechanism to ensure the administration does not act in a manner that would seriously erode fundamental values and principles. Maintaining these two paths recognises the many roles of courts in administrative law: to protect individual rights created by the legislature, the administration and the common law; to facilitate good administration; and to prevent actions of the administration from undermining fundamental principles of the common law that are not in and of themselves specific enough to create legally enforceable rights.

\section{CONCLUSION}

Substantive legitimate expectations are a fairly recent development in the common law. Consequently, it is no surprise that we can point to examples of a lack of clarity in the law, or how it applies to particular situations, as well as divergence regarding the scope of this head of review, the values and principles underpinning the law and the approach to legal reasoning that should be adopted by courts. This article has attempted to carry on in the spirit of Forsyth's original article, seeking clarification and assessing potential reforms.

It has argued that clarification can be achieve in this area of the law by recognising the emergence of a core case of substantive legitimate expectations. However, it has also argued that we should not confine the protection of substantive legitimate expectations to this core case. Whilst doing so may help judicial review to protect individual rights and facilitate good administration, it may also create situations in which substantive equality is not protected. If we are to ensure that judicial review also performs its further function of upholding the rule of law through acting as a constitutional safeguard, there also needs to be space for courts to apply a principled approach to substantive legitimate expectations which do not fall within the core case.

This is not to argue that there will be no uncertainties in future case law. As Pathan amply demonstrates, the distinction between substance and procedure can be difficult to apply in practice and an array of criteria have been suggested to help draw the line between the two. ${ }^{91}$ Moreover, uncertainty

${ }^{91}$ Pathan [2020] UKSC 41. 
still exists over some aspects of the core case of substantive legitimate expectations: for example, whether the burden of proof that there are good reasons for resiling from a promise or expectation rests with the public body or the individual; the extent to which past practice may establish a substantive legitimate expectation; and when a right to consultation arises from a procedural legitimate expectation, a secondary procedural legitimate expectation or an application of the principles of natural justice to the fact that an applicant has a substantive legitimate expectation. These difficulties may best be ironed out by a continued application of a combination of a doctrinal and a principled approach to legal reasoning in this area. To do so would neither permit courts to make purely intuitive decisions, nor mean that legitimate expectations collapse into "an inchoate justification for judicial intervention", which merely "plays a rhetorical role". 92 This may come at the price of legal certainty. However, this is a small price to pay to ensure the maintenance of good administration and substantive equality, particularly as a relatively youthful doctrine of the common law continues to develop.

\footnotetext{
92 Forsyth, "Legitimate Expectations Revisited", 429.
} 